\title{
礫養浜と突堤による検見川浜の緩傾斜護岸の 親水機能の向上
}

\author{
宮田＼cjkstart隆平1・小林 昭男 2 ・野志 保仁 3 ・宇多 高明4 \\ 1 日本大学理工学部海洋建築工学科（干274-8501 千葉県船橋市習志野台 7-24-1） \\ E-mail: csry13134@g.nihon-u.ac.jp \\ 2 正会員 日本大学教授理工学部海洋建築工学科（干274-8501 千葉県船橋市習志野台 7-24-1） \\ E-mail: kobayashi.akio@nihon-u.ac.jp \\ 3 正会員 日本大学助教理工学部海洋建築工学科（干274-8501 千葉県船橋市習志野台 7-24-1） \\ E-mail: noshi.yasuhito@nihon-u.ac.jp \\ 4 正会員 一般財団法人土木研究センターなぎさ総合研究所長兼日本大学客員教授理工学部海洋建築工 \\ 学科（干110-0016 東京都台東区台東 1-6-4）
}

緩傾斜護岸はその構造上のり先が砂磁で埋まっておれば安定であるが，侵食などによりのり先が露出 するとのり先から裏込め土砂の吸出しが起き, それがもとでのり面や背後地での陥没が起こることが多 い. また緩傾斜護岸ののり先が直接波に曝されると，のり先が生物付着のため滑りやすくなって転倒の 危険性が増すなどの障害も起こり得る。本研究では，このような状況が見られる東京湾湾奥にある検見 川浜を対象として，これらの障害を取り除く一つの方法として，護岸前面での碩養浜と突堤により砂浜 を回復し親水機能を高める方策について BG モデルを用いて検討した。

Key Words : gently sloping revetment, gravel nourishment, Kemigawa Beach, BG model, numerical simulation, beach changes

\section{1. まえがき}

高潮・津波被害を防止するために海岸には古くから護 岸が建設されてきた。様々な形式の護岸のうち，のり面 勾配が1/3以下の護岸は緩傾斜護岸と呼ばれており，これ らはのり面勾配が小さいため親水性の向上や景観への配 慮を目的として各地で造られてきた。一方，海岸侵食や 高波浪の作用に伴い各地で海岸護岸の被災も生じてきて いる. 護岸の被災に関する実態調査 ${ }^{19}$ によれば, 調査母数 の約半数が緩傾斜護岸であるとされている。これらの護 岸は，その構造上のり先が砂碩で埋まっておれば安定性 の確保が可能であるが，侵食などによりのり先が露出す ると，のり先から緩傾斜護岸の裏込め土砂の吸出しが起 き，それがもとでのり面や背後地での陥没が起こること も多い. また緩傾斜護岸ののり先が直接波に曝されると, のり先が生物付着のため滑りや寸くなって転倒の危険性 が増すなどの障害も起こり得る。そこで本研究では，こ のような状況が見られる東京湾湾奥に位置寸る検見川浜 を対象として，これらの障害を取り除く一つの方法とし て，緩傾斜護岸前面での碩養浜と礫の流出を防止する突
堤により砂浜を回復し，親水機能を高める方策について 野志ら2)によるBGモデルを用いて検討した。

\section{2. 検見川浜の現況}

検見川浜は東京湾湾奥に位置し, 東京湾を南西方向に望 む人工海浜である. 図-1 には検見川浜の衛星画像を示す. 海浜は沿岸方向に長さ $1.3 \mathrm{~km}$ を有しており, 南端と北端

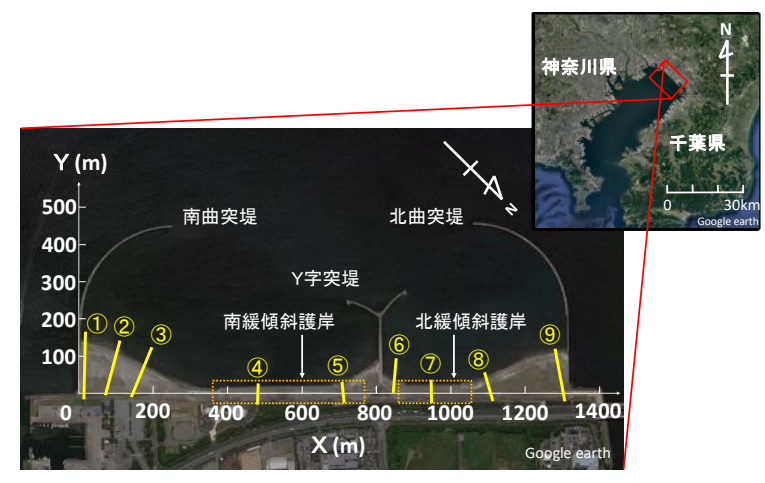

図-1＼cjkstart検見川浜の位置 


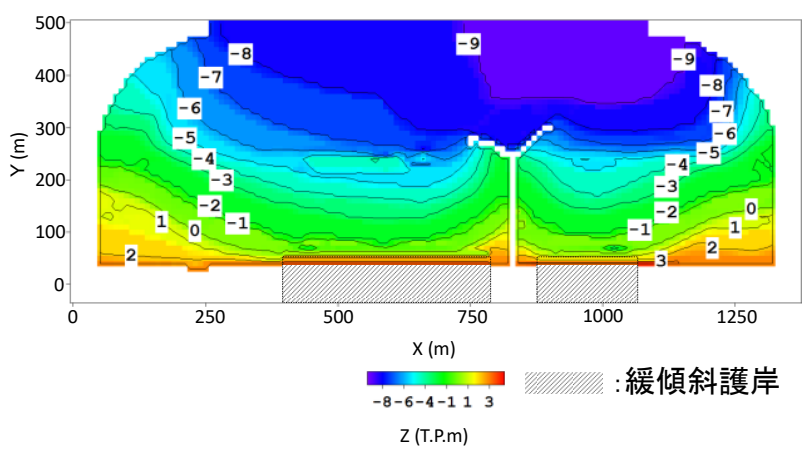

図-2 深浅図（2015 年 11 月測量）

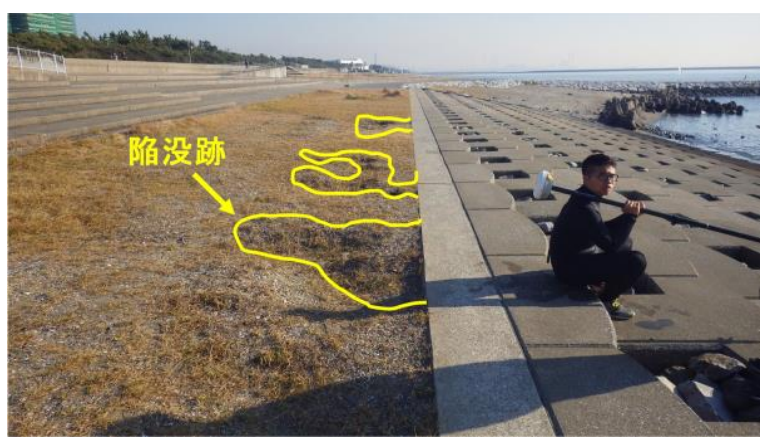

図-4 緩傾斜護岸背後での陥没（2016 年 12 月 21 日）

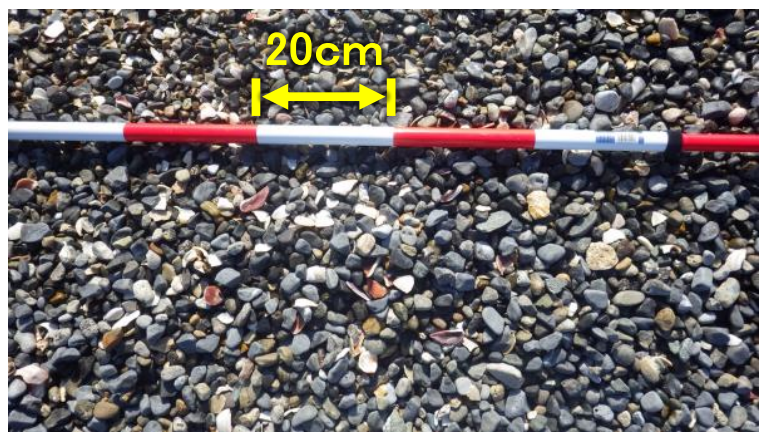

図-6 測線 5 の汀線際の底質

には曲突堤，さらに南曲突堤の北 $800 \mathrm{~m}$ にはY 字突堤が 造られている. 南曲突堤と $\mathrm{Y}$ 字突堤，および $\mathrm{Y}$ 字突堤と 北曲突堤間の海岸線には直線状の緩傾斜護岸が伸びてい る. 図-1 に示すように，南北の曲突堤による波の遮蔽効 果により，両端の曲突堤の隣接部には広い前浜が形成さ れているのと対照的に，Y 字突堤の両側近傍では砂が曲 突堤方向へと運び去られたため前浜が狭く，緩傾斜護岸 前面の砂浜の消失により護岸が波に曝された状態となっ ている. なお，図-1には南曲突堤から北曲突堤の間に配 置した 9 測線の位置を示寸.これらの測線上では 2016 年 8 月 3 日に縦断測量を行った. また, 図-2には 2015 年 11 月測量による検見川浜の深浅図を示寸。両端に位置する 曲突堤と中央部のY 字突堤がそれぞれ波の遮蔽効果を発 揮するために，これらの施設の背後では等深線が前進す る一方，それらに挟まれた区間では沿岸漂砂により砂が 運び去られたため凹状の等深線となっている.この四状 の等深線を持つ深みの底に緩傾斜護岸が設置されている

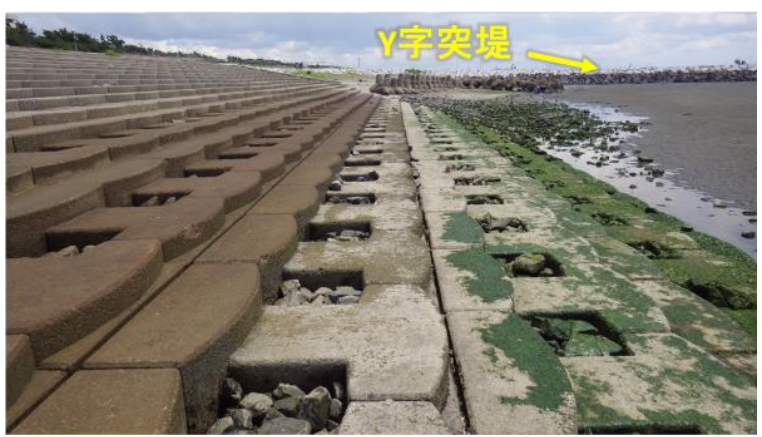

図-3 測線 7 付近の海岸状況（2016 年 8 月 3 日）

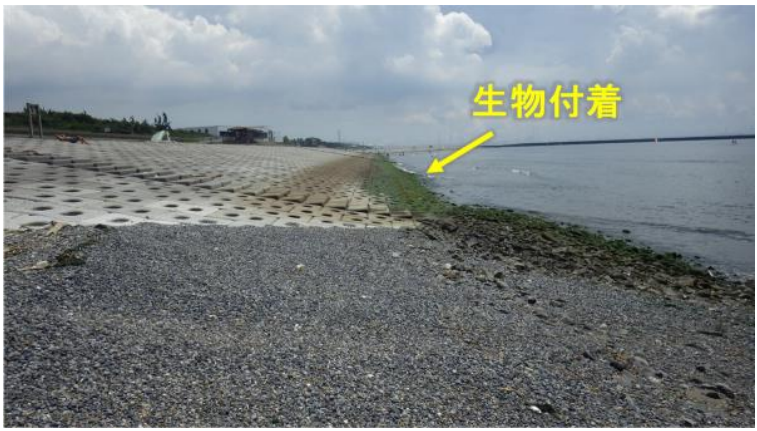

図-5 測線 5 付近の海岸状況（2016 年 8 月 3 日）

状態となっているため，緩傾斜護岸への波の作用が著し い.

例えば，図-3 は，図-1 の測線 7 付近において $\mathrm{Y}$ 字突堤 を望んで撮影した海岸状況を示す．緩傾斜護岸の前面が 露出し，海水と接する面は付着生物で覆われ，濡れた状 態では歩行が危険であった。護岸のステップは滑りや寸 くやすく緩傾斜護岸の持つ海岸へのアクセスのしやすさ からかけ離れていた。それだけでなく，測線７付近では 図-4に示寸ように，護岸の背後地盤において護岸裏込め 土砂が吸い出されて陥没が起きていた。陥没穴の一つは 直径 $1.2 \mathrm{~m}, 0.20 \mathrm{~m}$ の深さを有しており，また吸出しによ り陷没穴はいくつも確認できた（図-4）。一方，Y 字突堤 の南側に隣接する測線 5 付近では緩傾斜護岸ののり先は 碩で埋まっており, 測線 7 付近での護岸のり先が露出し, 生物付着が著しかったのと著しい対照を示した（図-5). このように汀線付近に碟が潤沢にあれば緩傾斜護岸のの り先を礫が覆うことにより，護岸ののり先が保護される ことが分かる. しかしながら図-5において礫浜の前方(南 側）では，測線 7 と同様護岸のり先が露出し，潮間帯付 近では生物付着が著しかった。これは汀線付近に堆積し うる砂礫の量が不足しているためその部分に堆積できな かったことによる. 図-6には測線 5 の汀線付近の海浜材 料を示す. 海浜材料は直径 $15 \mathrm{~mm}$ ほどの碩が大半を占め ており，また碩は丸みを帯び 海浜利用上も障害にはなっ ていなかった。 


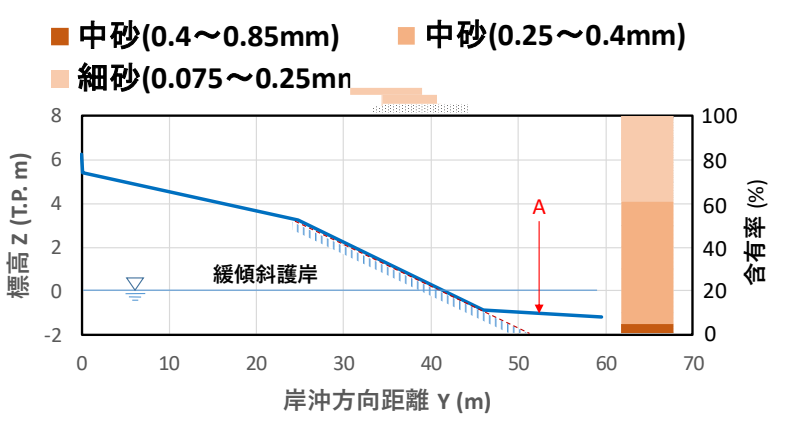

図-7 縦断形および粒度組成（測線 7）

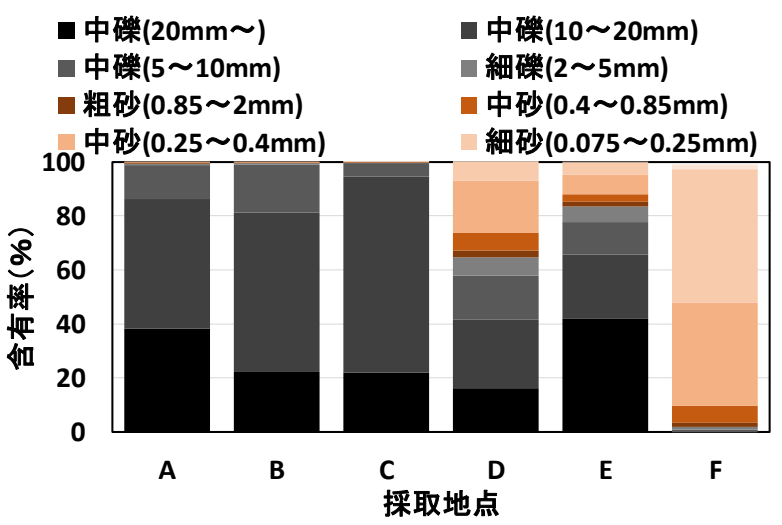

図-9 粒度組成（測線 5)

\section{3. 海浜断面の特徴}

2016 年 8 月 3 日, 図-1 に示したように沿岸に 9 測線を 設定し, RTK-GPSによる縦断形測量とともに代表地点で 底質サンプリングを行った. また海岸状況の踏査を行い, 海岸状況写真を撮影した。観測結果として，まず測線 7 上の地点 A で採取した底質の粒度組成を図-7 に示す. 緩 傾斜護岸ののり先は波に曝されていたが，そののり先の 海底面には中砂と細砂が堆積し，これら両者の含有率は 全体の 96\%を占めていた。また A 付近での海底勾配は 1/42 と緩やかであった。同じく図-8,9 には測線 5 での縦 断形と粒度組成を示寸. 緩傾斜護岸ののり先の標高 $1.2 \mathrm{~m}$ 以下で堆積が起きていた。この測線では図示する地点 $\mathrm{A}$ 〜F で底質を採取し粒度組成を調べたが，のり先の地点 $\mathrm{A} \sim \mathrm{E}$ には主に礫が堆積し，のり先より沖の地点 $\mathrm{F}$ には 中砂および細砂が堆積していた。地点 $\mathrm{E}, \mathrm{F}$ の間が干潮時 汀線であることから，干潮時汀線より陸側には礫が堆積 し, その沖では中砂細砂が堆積していることが分かった.

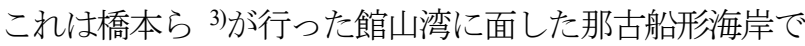
の観測において，前浜には相対的に粒径の大きな砂が堆 積する一方，沖合では粒径の細かい砂が分かれて堆積し ていたのと同じ傾向である．検見川浜では A〜E での礫 浜の公配は $1 / 6.8$ であった。 また測線 5 上の地点 $\mathrm{F}$ 付近 の勾配は 1/14 と緩くなり, 粒度組成は測線 7 の地点 $\mathrm{A}$ の それと酷似していた。

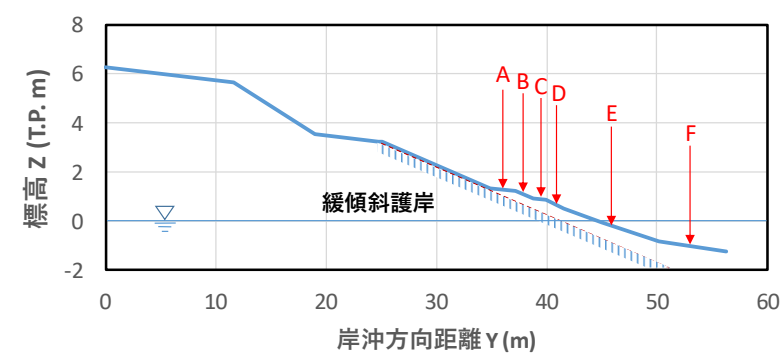

図-8 縦断形（測線 5)

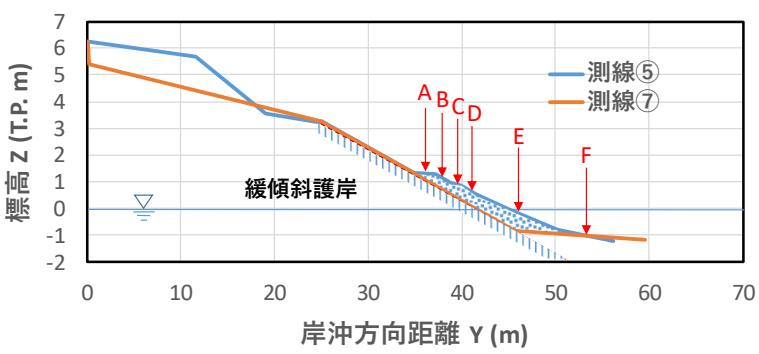

図-10＼cjkstart測線 5,7 における縦断形の重ね合わせ

表-1 計算条件

\begin{tabular}{|c|c|c|}
\hline & 初期勾配 & $1 / 50$ \\
\hline & 初期粒径と含有率 & $15 \mathrm{~mm}, 100 \%$ \\
\hline & 平衡勾配 & $1 / 6.8$ \\
\hline & 交換層幅 B(m) & 1.35 \\
\hline \multirow{4}{*}{ 入射波条件 } & 碎波波高 $H_{b}(\mathrm{~m})$ & 1 \\
\hline & 周期 $T(\mathrm{~s})$ & 4 \\
\hline & 碎波波向 $\alpha$ (deg) & 0 \\
\hline & 潮位条件 M.S.L.(m) & 0 \\
\hline \multirow{2}{*}{ 地形変化の水深範囲 } & 地形変化の限界水深 $h_{c}(\mathrm{~m})$ & 3.5 \\
\hline & バーム高 $h_{R}(\mathrm{~m})$ & 1.5 \\
\hline \multirow{3}{*}{ 漂砂量係数 } & 漂砂量係数 A & 0.5 \\
\hline & 小笹プランクトン項の係数 & 0.5 \\
\hline & 岸沖・沿岸漂砂量係数比 & 0.2 \\
\hline \multirow{2}{*}{ 土砂落ち込みの限界勾配 } & 陸域 & $1 / 2$ \\
\hline & 海域 & $1 / 3$ \\
\hline \multirow{2}{*}{ 計算範囲 } & 沿岸方向 $X(\mathrm{~m})$ & $0 \sim 1370$ \\
\hline & 岸沖方向 $Y(m)$ & $-30 \sim 500$ \\
\hline \multirow{2}{*}{ 計算メッシュ } & $\Delta X(\mathrm{~m})$ & 10 \\
\hline & $\Delta Y(\mathrm{~m})$ & 10 \\
\hline \multicolumn{2}{|r|}{ 計算時間間隔 $\Delta t(h)$} & 0.1 \\
\hline \multicolumn{2}{|r|}{ 計算ステップ数 } & $2,000,000$ \\
\hline
\end{tabular}

以上の観測結果をまとめ，図-10 には測線 5 と 7 の縦 断形の重ね合わせ図を示す。いずれの場所でも緩傾斜護 岸の勾配は 1/3 であるが，測線 5 の緩傾斜護岸前面は砂 碩で覆われているのに対し，測線 7 では砂礫の堆積はな く緩傾斜護岸ののり先が露出している.このことから， 以下の検討では護岸ののり先が露出した測線 7 の状況を 測線 5 のようにのり先が砂碟で覆われた状況に改良でき ないかとの視点から検討を進めた。

\section{BG モデルによる養浜時地形変化予測}

\section{(1) 計算条件}

本研究では野志ら ${ }^{3)}$ による BG モデルを用いて検討を 進めたが，それに必要な諸条件は現地状況を基に設定し 
た．碩養浜のモデル計算を進める上で必要とされるパラ メータを一括して表-1に示寸．投入碩の粒径は現況の検 見川浜に堆積している硯と同じ $15 \mathrm{~mm}$ とし，平衡勾配は 測線 5 で実測した前浜勾配 1/6.8 が安定していると判断 できるので，これを平衡勾配に等しいとした．波は直角 入射とし, バーム高を $1.5 \mathrm{~m}$, 波による地形変化の限界水 深を $3.5 \mathrm{~m}$ とした．また，図-2 に深浅図を示寸現況の検 見川浜は, 施設が 1999 年に完成後十分長い時間が経過し ていることから地形変化はほぼ終息していると考えられ る. そこで図-2に示す海底地形を固定床とみなし，その 状態で碩を投入して砂の移動による地形変化を調べた。

碩養浜の計算は，碩の流出防止を図る突堤のない場合 と, 突堤ありの場合に分けるとともに，養浜量を 2 種類 変え，全体で 4 ケースの計算を行った. Case 1, 2 は碩の 流出防止のための突堤のない条件で, Case 1 では, 緩傾 斜護岸の面積の $30 \%$ に相当する前浜の創出を目指して, 南側，北側の緩傾斜護岸の前面に $7,000 \mathrm{~m}^{3}, 3,000 \mathrm{~m}^{3}$ の養 浜を行った. この場合, 南側の緩傾斜護岸の前面では 10 $\mathrm{m}$ 幅で長さ $390 \mathrm{~m}$ の範囲に碩を敷き詰め，北側の護岸前 面でも同様に $10 \mathrm{~m}$ 幅で長さ $190 \mathrm{~m}$ の範囲に礫を敷き詰 めた。 また養浜時の海浜の高さは $2 \mathrm{~m}$ とした. Case 2 で は養浜量を増加させ，南北の緩傾斜護岸の前面に護岸で 覆われた面積の $100 \%$ 相当分の前浜の増加が得られるよ う，南側，北側の護岸前面にそれぞれ $26,000 \mathrm{~m}^{3}, 9,000 \mathrm{~m}^{3}$ の養浜を行った．この場合の土砂投入は，南側の緩傾斜 護岸の前面では幅 $30 \mathrm{~m}$ で長さ $390 \mathrm{~m}$ 区間で，また，北側 の護岸前面でも同様に幅 $30 \mathrm{~m}$ で長さ $190 \mathrm{~m}$ 区間に磁を 敷き詰めた。また養浜時の海浜の高さは Case 1 と同様に $2 \mathrm{~m}$ とした.

Case 3,4 では Case 1, 2 と養浜量，養浜区域を同一とし て，養浜区間の南端と北端に突堤を設置して養浜礫を投 入区域に留める手法について検討した。 この場合，図-8 によれば礫は汀線より陸側に集中的に堆積しており，水 深 $2 \mathrm{~m}$ ではみられなくなること，また同様な特徽は神向 寺海岸でも観察されたこと ${ }^{4)}$ から，本研究でも突堤の先 端水深が $2 \mathrm{~m}$ となるよう突堤長を $80 \mathrm{~m}$ とした. なお，い ずれのケースでも養浜材料に硫を用いた理由は，例えば 粒径が $0.2 \mathrm{~mm}$ 程度の細砂では平衡勾配が $1 / 30$ 程度と緩 やかで，安定な砂浜を造るためには岸沖方向の長い距離 にわたって砂が広がることを許す必要があるのに対し， 礫では実際に図-10 に示したように緩傾斜堤ののり面勾 配 1/3 よりは緩やかで,かつ細砂と比べて $1 / 7$ と急な勾配 で堆積し，護岸ののり先をうまく砂碩に埋めることが可 能なことによる．このことはまた礫の調達量が少なくて 済むことも意味している。

\section{(2) 計算結果}

南側の緩傾斜護岸の前面に $7,000 \mathrm{~m}^{3}$ ，北側の護岸前面
に 3,000 $\mathrm{m}^{3}$ の碩養浜を行った Case 1 の計算結果を図-11 に示す．北側の護岸前面に投入された碩は，沿岸漂砂に より投入点から南北両側に広がった．前浜は広がったも のの前浜の拡幅が最も望まれる護岸中央部での碟の堆積 量は少なく，中央部で前浜を拡げるという目的を達成で きなかった．また，南側の護岸前面においても投入礫は 南北方向に移動し，中央部での護岸のり先の露出は防ぐ
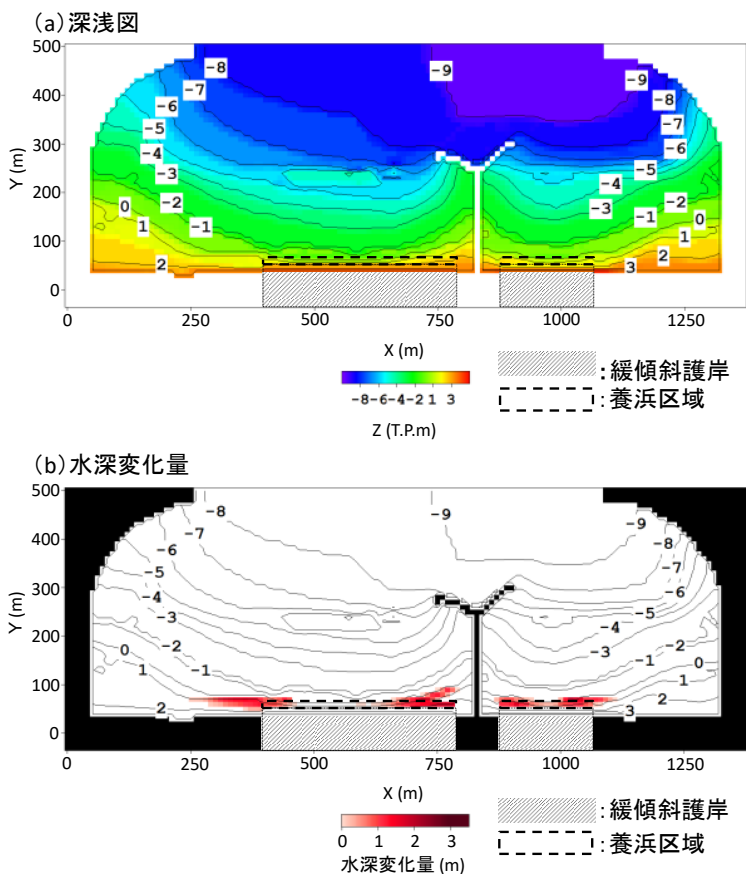

図-11＼cjkstart養浜後の深浅図および水深変化量(Case 1, $10,000 \mathrm{~m}^{3}$ 養浜)
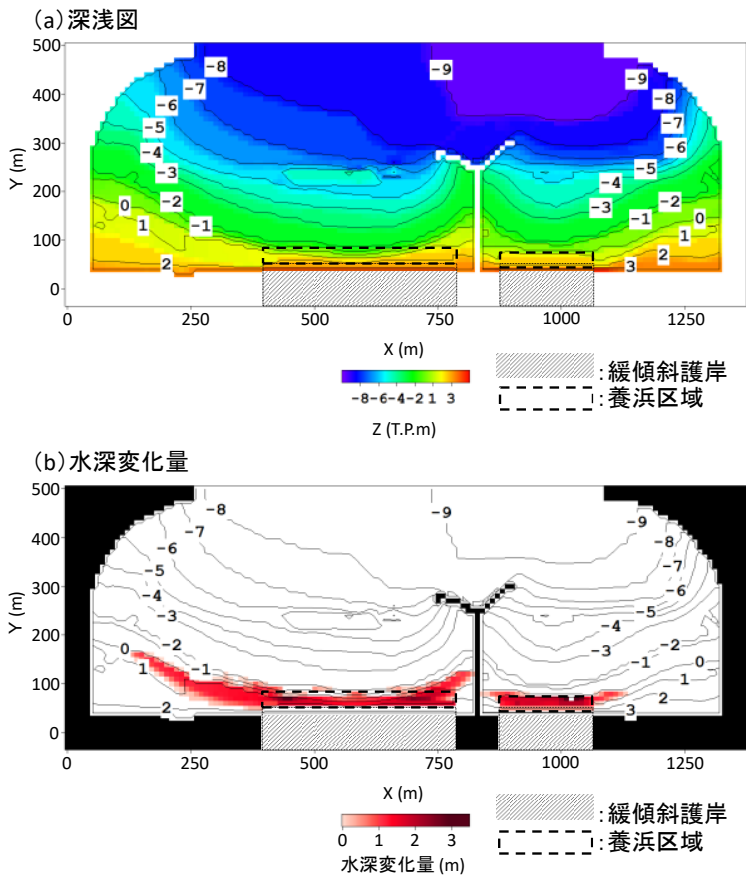

図-12＼cjkstart養浜後の深浅図および水深変化量(Case 2, $35,000 \mathrm{~m}^{3}$ 養浜) 


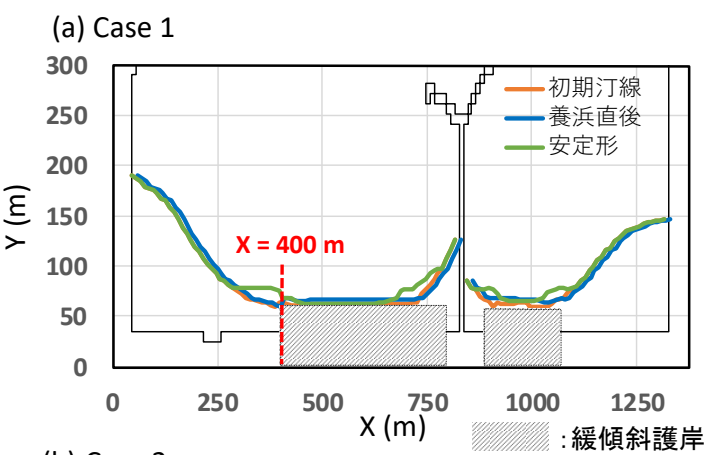

(b) Case 2

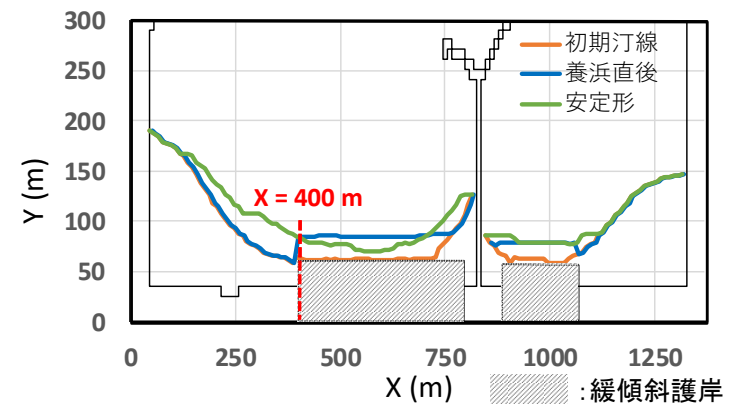

図-13 養浜前後の汀線変化

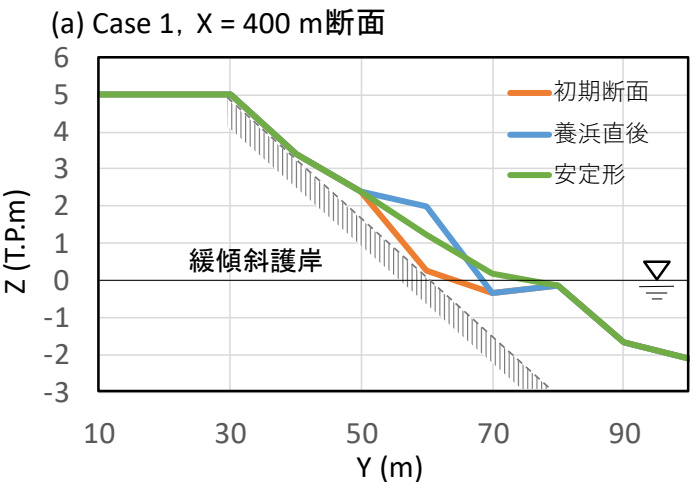

(b) Case 2, X= 400 m断面

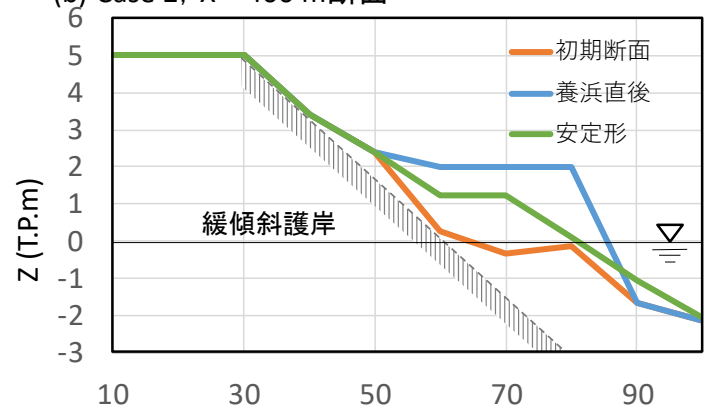

図-14 養浜前後の縦断形変化

ことができなかった．同様にして養浜量を南北それぞれ 26,000 $\mathrm{m}^{3}, 9,000 \mathrm{~m}^{3}$ と養浜量を増した Case 2 の計算結果 を図-12 に示寸. Case 2 でも北側の護岸前面では, 㗂の養 浜を行ったとしても投入礫は沿岸漂砂により南北方向に 運ばれてしまい, 緩傾斜護岸中央部への堆積はわずかと なった．また，南側の護岸前面では北側よりも沿岸漂砂 による影響が明確に出ており, 護岸中央部への堆積量は 少なかった．投入碩の大半は曲突堤背後の波の遮蔽域方
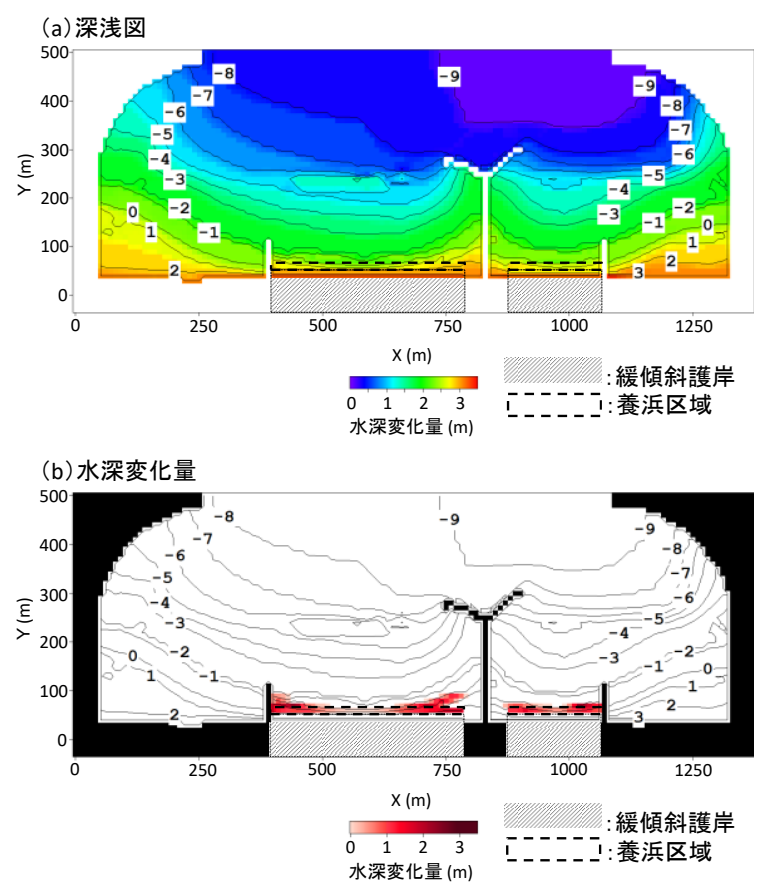

図-15 突堤設置後の深浅図および水深変化量(Case $3,10,000 \mathrm{~m}^{3}$ 養浜)
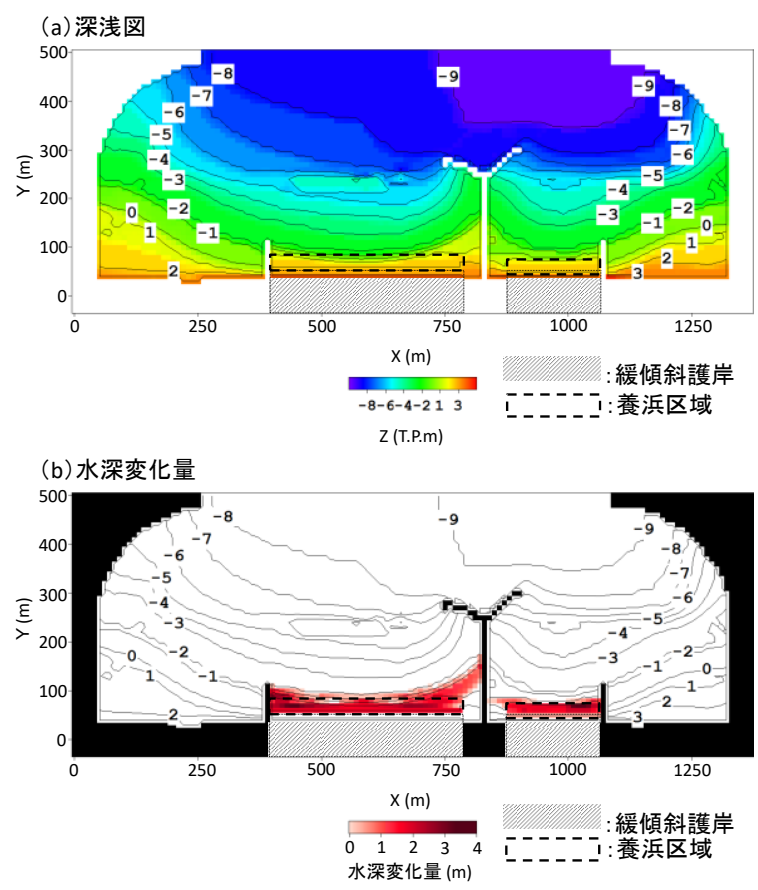

図-16 突堤設置後の深浅図および水深変化量(Case $4,35,000 \mathrm{~m}^{3}$ 養浜)

向へ移動し，護岸前面には㗂がわずかしか堆積しないと いう結果となった.

養浜前後の汀線変化を図-13 に示寸. Case 1, 2 ともに, 養浜直後には緩傾斜護岸前面で汀線が前進したものの時 間経過とともに養浜土砂が主に沿岸方向に流出したため に汀線が後退した。 その際，Y 字突堤の北側では護岸前 面の深夕を磎が埋めたため, Y 字突堤近傍での汀線の前 進量は小さくなった. さらに, Case 1,2 について, 図-13 


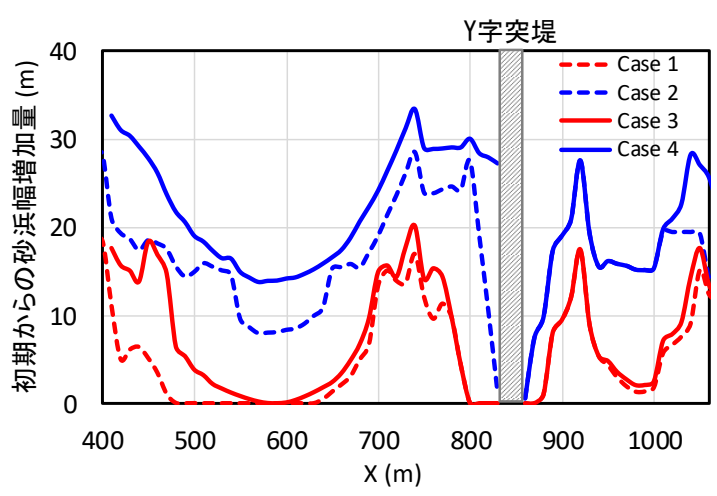

図-17 初期加らの砂浜幅増加量

に示す $X=400 \mathrm{~m}$ 断面における養浜前後の断面変化を図14 に示す. 護岸全面にあった凹状部分を埋めて養浜が行 われた後，再び土砂が流出したが，最終的に平衡勾配に 等しい勾配の断面となった.

養浜碟は沿岸漂砂により両端部へと運ばれたことから， Case 3, 4 では養浜区間の南端と北端に突堤を設置するこ とにより養浜礫を投入区域に留める方向についても検討 した. Case 3 の計算により得られた深浅図と初期からの 水深変化量を図-15 に示す. 北側の護岸前面ではもとも と北側への流出磁が少なかったため，突堤先端を超えて 土砂が流出することはなかった。一方，南側の護岸前面 中央部は露出したことから，より多くの養浜が必要とな る.これを検討した Case 4 の結果を図-16 に示す。南側 の突堤先端まで土砂が堆積しているが, 突堤先端を超え, 流出することはなかった．緩傾斜護岸設置区域における 初期からの砂浜幅の増加量を図-17 に示す. Y 字突堤の 北側では突堤の有無による差はあまりないが，南側では 中央部付近の浜幅が大きく広がり，突堤の設置効果が顕 著に現れたことが分かる。

\section{5. まとめ}

検見川浜では, 南北緩傾斜護岸の前面に総量 $35,000 \mathrm{~m}^{3}$ の養浜を行うとともに，養浜区域の両端に砶の流出防止 のために先端水深 $2 \mathrm{~m}$, 長さ $80 \mathrm{~m}$ の突堤を設置すれば, 現況で波に曝された緩傾斜護岸ののり先を碟で覆うこと により防護・利用条件の向上に役立つことが分かった. 一方で，突堤を設置したことによる突堤自体への生物付 着や突堤からの転落の危険性が考えられるが，これらに 対しては柵を設ける等の対策が必要と考えられる. なお, 両側に波の遮蔽構造物が造られた場合に海浜中央部で砂 浜幅が大きく狭まり，海岸利用上の障害となったり，あ るいは護岸からの越波が増すなどの現象は各地で起きて いる.このような場合，そこに消波構造物を設置すると 景観の低下を招くことから，海浜中央部の砂浜幅を広げ ることが望ましい，粗粒材養浜の行われた茨城県の神向 寺海岸の 6, 7 号へッドランド間中央部でも同様な現象が 起き, 本論文と同様な検討が行われた ${ }^{4)}$. これより本研究 で述べた手法は他の海岸での同種の問題にも適用が可能 と考えられる.

\section{参考文献}

1) 加藤史訓，野口賢二，諏訪義雄 : 海岸堤防・護岸の被 災に関する実態調査, 土木学会論文集 B3 (海洋開発), Vol.67, No.2, p.I_7-I_12, 2011.

2) 橋本佳樹，小林昭男，宇多高明，野志保仁 : 砂浜干潟 併存場において前浜と干潟面を分ける遷急線と汀線 との斜交現象, 土木学会論文集 B2 (海岸工学), Vol.72, No.2, pp.I 559-I 564, 2016.

3) 野志保仁, 宇多高明, 芹沢真澄, 熊田貴之, 酒井和也 : 粒度組成を考慮した平衡勾配概念および Bagnold 概念 に基づいた地形・粒径変化予測モデル，土木学会論文 集 B2 (海岸工学), Vol.65, No.1, pp.501-505, 2009.

4) 宇多高明, 芹沢真澄, 宮原志帆, 大木康弘 : 神向寺海 岸の 6,7 号ヘッドランド間中央部の前浜拡幅手法，土 木学会論文集 B3 (海洋開発), Vol.71, No.2, p.I_748I_753, 2015.

(2017.2.2 受付)

\section{IMPROVEMENT OF WATERFRONT FUNCTION OF GENTLY SLOPING REVETMENT BY GRAVEL NOURISHMENT}

\section{Ryuhei MIYATA, Akio KOBAYASHI, Yasuhito NOSHI and Takaaki UDA}

The gently sloping revetment is stable when the toe of the revetment is buried beneath the sandy beach. However, when the toe of the revetment is exposed to waves as a result of beach erosion, fill material under the revetment is drawn out through the gap between the toe and sandy beach, resulting in the damage of the entire gently sloping revetment. Furthermore, when the toe of the revetment is exposed to waves, the revetment tends to be slippery because of the attachment of marine organisms, causing the increase in danger of the falling. In this study, the recovery method of sandy beach in front of the gently sloping revetment using gravel nourishment is discussed as a measure to improve the waterfront function, taking Kemigawa Beach in Tokyo Bay as an example. Numerical simulations were carried out using the BG model. 